ZOOLOGIA 32 (1): 66-70, February 2015

http://dx.doi.org/10.1590/S1984-46702015000100010

\title{
Two new species of Triplectides (Trichoptera: Leptoceridae) from South America
}

\author{
Ana Lucia Henriques-Oliveira' ${ }^{1,2} \&$ Leandro Lourenço Dumas ${ }^{1}$
}

\author{
${ }^{1}$ Universidade Federal do Rio de Janeiro, Laboratório de Entomologia, Departamento de Zoologia, Instituto de Biologia, \\ Caixa Postal 68044, Cidade Universitária, 21941-971, Rio de Janeiro, RJ, Brazil. \\ 2 Corresponding author: anahenri@biologia.ufrj.br
}

\begin{abstract}
Triplectides, with about 70 extant species, is the most diverse genus within the Triplectidinae. In the Neotropical Region there are 14 species distributed from southern Mexico to Patagonia. Two new species of Triplectides from the Neotropics are described and illustrated based on the male genitalia: Triplectides cipo sp. nov., from state of Minas Gerais, southeastern Brazil, and Triplectides qosqo sp. nov., from province of Cuzco, southern Peru. The news species can be distinguished by the male genitalia: Triplectides cipo sp. nov. can be recognized by having the inferior appendages with mesal lobes subacute and apical lobes short, and the tergum $\mathrm{X}$ robust, with a subtruncate apex and deep mesal notch; Triplectides qosqo sp. nov. can be recognized by the first article of inferior appendages long and narrow when compared to the others Triplectides species and by the tibial spur formula 2,2,4.
\end{abstract}

KEY WORDS. Brazil; Caddisflies; new species; Peru; Triplectidinae.

Leptoceridae is one of the most diverse families of caddisflies, with almost 2,000 described species (Morse 2011). The family is divided into two subfamilies: Leptocerinae Leach, with cosmopolitan distribution, and Triplectidinae Ulmer, which is primarily distributed in the Southern Hemisphere (Holzenthal et al. 2007). Triplectides Kolenati, 1859 is the most species-rich genus within Triplectidinae, with about 70 species (Holzenthal 1988, Malm \& Johanson 2008). The genus occurs in Central and South America, Southern-East Asia (India to Japan), and especially in Oceania, where it reaches its highest diversity, with 15 and 25 species recorded from New Caledonia and Australia, respectively (MaLm \& Johanson 2008).

Mosely (1936) provided the first comprehensive revision of the genus. Later, the Neotropical species were reviewed by Holzenthal (1988). Since then, only one species has been described from the Neotropics (Dumas \&Nessimian 2010). Currently, there are 14 species described from the Neotropical Region, distributed from Southern Mexico to Southern Chile: Triplectides chilensis Holzenthal, 1988 (Argentina and Chile), T. colombicus Navás, 1916 (Colombia), T. egleri Sattler, 1963 (Brazil, Guyana, and Surinam), T. flintorum Holzenthal, 1988 (Colombia, Costa Rica, Ecuador, Guatemala, Honduras, Mexico, Nicaragua, Panama, Peru, and Surinam), T. gracilis (Burmeister, 1839) (Argentina, Brazil, Paraguay, and Surinam), T. itatiaia Dumas \& Nessimian, 2010 (Brazil), T. jaffuelli Navás, 1918 (Argentina and Chile), T. misionensis Holzenthal, 1988 (Argentina and Brazil), T. neblinus Holzenthal, 1988 (Venezuela), T. neotropicus Holzenthal, 1988 (Brazil and Venezuela), T. nevadus Holzenthal, 1988 (Peru and Venezuela), T. nigripennis Mosely, 1936 (Argentina and Chile), T. tepui Holzenthal, 1988 (Venezuela), and T. ultimus Holzenthal, 1988 (Brazil).

In the present work, we describe and illustrate two new species from South America: Triplectides cipo sp. nov. from the state of Minas Gerais, southeastern Brazil, and Triplectides qosqo sp. nov. from province of Cuzco, southern Peru.

\section{MATERIAL AND METHODS}

Specimens were collected with malaise and light traps and were preserved in $80-96 \%$ ethanol. In order to observe the genital structures, the abdomen was removed and cleared using the lactic acid method (BLAHNIK et al. 2007). The abdomens were mounted on temporary slides with glycerin for viewing and drawing, and transferred back to ethanol and permanently stored in micro vials. Pencil illustrations were made under a stereomicroscope or under a compound microscope, both equipped with a camera lucida. Pencil drawings of genital structures were inked with a technical pen, and wing illustrations were made using vector lines in an Adobe Illustrator (v. 16, Adobe Inc.) document. The terminology used in this paper follows that presented by HoLzenthal (1988).

Type specimens are deposited in the following collections, as indicated in descriptions: Museo de Historia Natural "Javier Prado", Universidad Nacional Mayor de San Marcos, Lima (MUSM) and Coleção Entomológica Professor José Alfredo Pinheiro Dutra, Departamento de Zoologia, Universidade Federal do Rio de Janeiro, Rio de Janeiro (DZRJ). 


\section{TAXONOMY}

\section{Triplectides cipo sp. nov.}

Figs. 1-7

Description. Adult male. General color brown (in alcohol). Antennae, palps and legs golden brown. Head and thorax mostly brown. Forewings with forks I and V present in males; discoidal cell apically large. Hind wings broad, with forks I, III, and V present; fork I with distinct petiole. Length of forewing 10.0-11.0 mm, length of hind wing 8.0-9.0 $\mathrm{mm}(\mathrm{n}=5)$ (Fig. 1). Tibial spur formula 2,2,4.

Genitalia. Segment IX, in lateral view, narrow with anterior margin almost straight and enlarged dorsally, posterior margin slightly concave medially (Fig. 3); tergum IX with posterior margin almost rounded, slightly protruding laterally, median process apparently absent (Figs. 2 and 3). Preanal appendages slender, digitate, slightly longer than half length of tergum X, bearing long setae (Fig. 2). Tergum X, in lateral view, wide at base, tapering apically, with apex rounded; in dorsal view, slightly widened apically, apex subtruncate, bearing small setae, with apicomesal excision extending anteriorly at half length of segment (Fig. 3). Inferior appendages, long, slightly surpassing tergum $X$, bearing long setae; $1^{\text {st }}$ article, as viewed laterally, wide at base, constricted medially, with apical portion narrow; apicodorsal lobe club-like, with long setae; basoventral lobes digitate, bearing long setae; in ventral view, mesal lobes shorter than basoventral lobes, wide at base, tapering apically, with flattened aspect, apex subacute; $2^{\text {nd }}$ article short, wide at base, tapering apically, gradually curved inward, with pointed apex (Fig. 5). Phallic apparatus simple, tubular, with phallotremal sclerite small, rod-like, apically positioned (Fig. 6).

Adult female. General color brown (in alcohol). Antennae, palps, and legs golden brown. Thorax and head brown. Length of forewing 13.5-14.5 mm, length of hind wing 10.5$11.5 \mathrm{~mm}(\mathrm{n}=3)$. Tibial spur formula 2,2,4.

Genitalia. Sternum VIII, in ventral view, with a sclerotized plate, dark brown; anterior margin deeply concave, posterior margin truncate with a small mesal cleft, with several short setae (Fig. 7). Sternum IX heavily sclerotized, with small transverse striae apically. Appendages of segment X, in lateral view, short, broad at base, subtriangular and setose (Fig. 6). Sensilla-bearing process absent. Valves ventrolateral, well developed, sclerotized, flap-like, slightly concave with fine setae (Fig. 6). Internal vaginal apparatus long, broad, and sclerotized (Fig. 7).

Holotype male: BrazIL, Minas Gerais: Jaboticatubas (Parque Nacional da Serra do Cipó, Córrego das Pedras, 19²2’16.7"S, 48³6'2.8"W, 766 m), 9-13.xii.2011, Malaise trap, APM Santos, DM Takiya, RR Cavichioli \& ML Monné leg. (DZRJ). Paratypes: same data as holotype, 1 male, 2 females (DZRJ); Minas Gerais: Jaboticatubas (Parque Nacional da Serra do Cipó, Córrego das Pedras, $19^{\circ} 22^{\prime} 16.7^{\prime \prime S}, 48^{\circ} 36^{\prime} 2.8^{\prime \prime} \mathrm{W}, 766$ m), 02-05.iii.2013, Mal- aise trap, BHL Sampaio, BM Camisão, ALH Oliveira, APM Santos \& DM Takiya leg. (15 males, 6 females) (DZRJ).

Distribution. Brazil (state of Minas Gerais).

Etymology. The specific epithet, cipo, refers to the type locality of the species, Parque Nacional da Serra do Cipó, located in Serra do Espinhaço mountain range.

Remarks. Triplectides cipo sp. nov. is closely related to $T$. flintorum Holzenthal, 1988 and T. itatiaia Dumas \& Nessimian, 2010 as evidenced by the wing venation and mesal lobes of inferior appendages. In T. cipo the hind wing fork I is petiolate, as in the other two similar species cited above. However, the genital structure of the new species is quite distinct from those of T. flintorum and T. itatiaia. The mesal lobes of inferior appendages of $T$. cipo are less rounded apically, being subacute. Also, the apical lobes of the inferior appendages of the new species are comparatively shorter than those of $T$. flintorum and T. itatiaia. In addition, in T. cipo tergum $\mathrm{X}$ is robust, with a subtruncate apex and deep mesal notch, whereas in T. itatiaia it is rounded apically. Triplectides flintorum also has tergum X subtruncate apically but the mesal notch is less deep than in $T$. cipo.

\section{Triplectides qosqo sp. nov.}

Figs. 8-12

Description. Adult male. General color brown (in alcohol). Antennae and palps brown. Legs light brown. Forewings with forks I and V present in male; discoidal cell slightly narrower at apex. Hind wings broad, with forks I, III, and V present; fork I with distinct petiole. Length of forewing 12.0-13.0 mm, length of hind wing 9.5-10.0 $\mathrm{mm}(\mathrm{n}=6)$ (Fig. 8). Tibial spur formula $2,2,4$.

Genitalia. Segment IX, in lateral view, annular, narrow with anterior margin almost straight and enlarged dorsally, posterior margin slightly protruded near dorsum (Fig. 10); tergum IX with posterior margin almost rounded, slightly protruding laterally (Figs. 9 and 10). Preanal appendages rounded and slightly flat, more than half length of tergum $\mathrm{X}$, bearing long setae (Fig. 9). Tergum X, in lateral view, wide at base, anterodorsal area less sclerotized, slightly tapering apically, with apex rounded; in dorsal view, apex subtruncate, slightly narrower than base, bearing small setae, with apicomesal excision extending slightly beyond apical third of segment (Figs. 9 and 10). Inferior appendages long, surpassing tergum $X$, bearing long setae; $1^{\text {st }}$ article, in lateral view, wide at base, constricted before half length of segment, with apical portion narrow; apicodorsal lobe digitate, with long setae; basoventral lobes digitate, tapering to apex, bearing long setae; in ventral view, mesal lobes shorter than basoventral lobes, wide at base, tapering apically, with pointed apex, bent outward, flattened in lateral view; $2^{\text {nd }}$ article short, wide at base, tapering apically, gradually curved inward, with pointed apex (Figs. 10 and 12). Phallic apparatus simple, tubular, with phallotremal sclerite small, rod-like, mesally positioned (Fig. 11). 

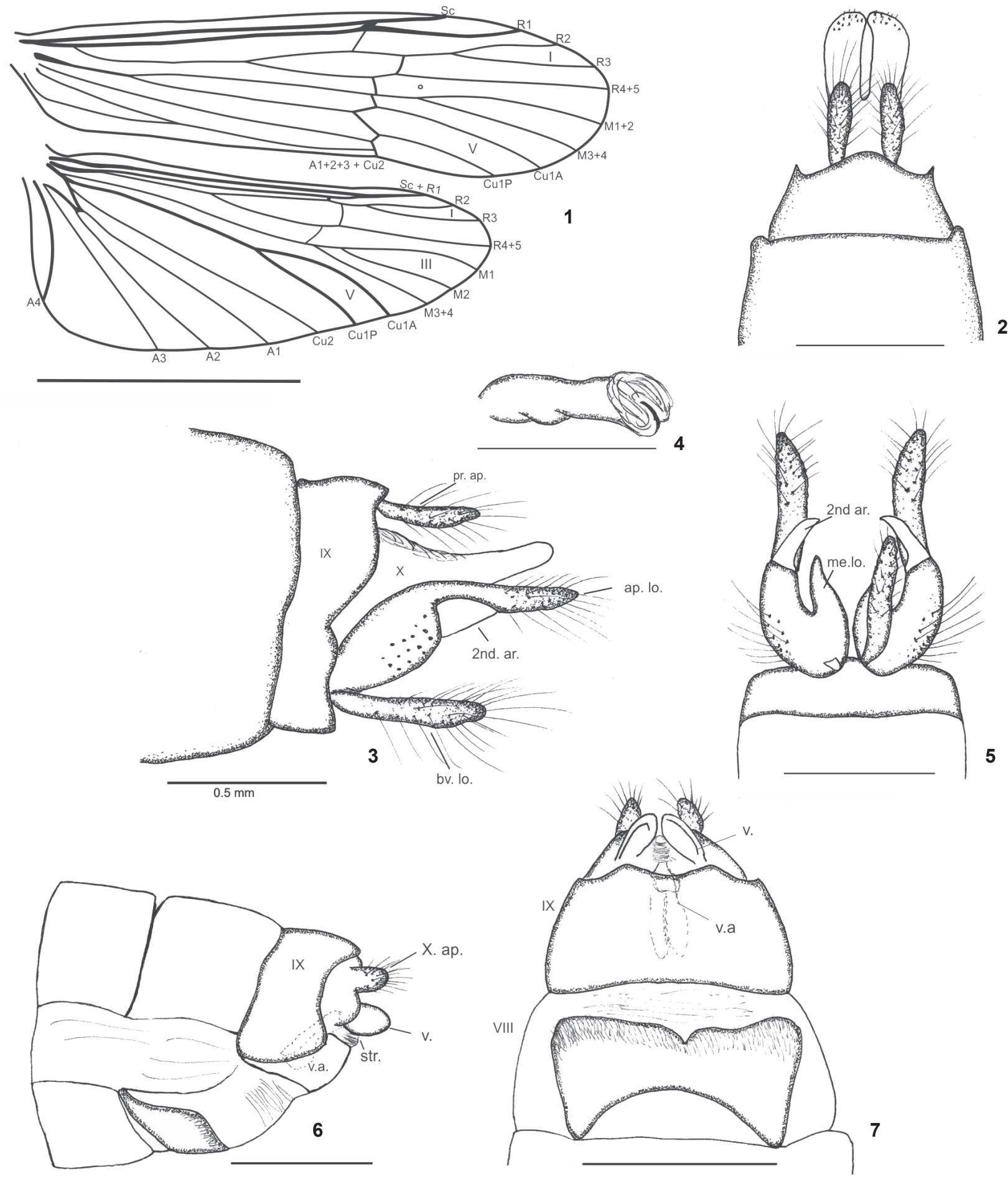

Figures 1-7. Triplectides cipo sp. nov. (1-5) Male: (1) fore and hind wings; (2) genitalia, dorsal view; (3) genitalia, lateral view; (4) phallic apparatus, lateral view; (5) genitalia, ventral view. (6-7) Female: (6) genitalia, lateral view; (7) genitalia, ventral view. (IX) Tergum IX, (X) Tergum X, (pr. ap.) preanal appendages, (ap. lo.) apicodorsal lobe, (bv. lo.) basoventral lobe, (me. lo.) mesal lobe, (2nd ar.) second article, (X. ap.) appendages of segment $X,(v$.$) valves, (str.) striae, (v.a.) vaginal apparatus. Scale bars: 1=5.0 \mathrm{~mm}, 2-5=0.5 \mathrm{~mm}, 6-7=1.0 \mathrm{~mm}$. 

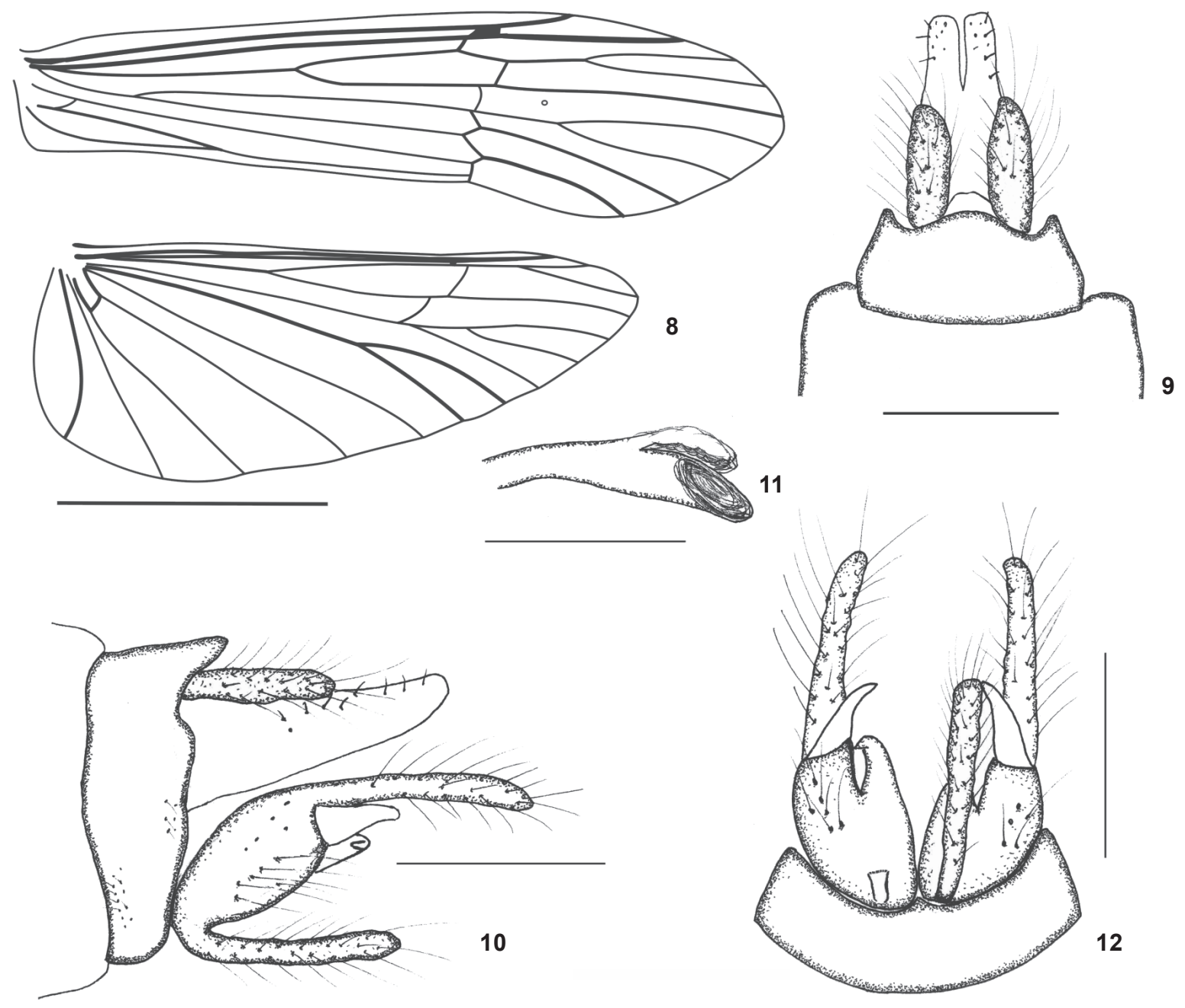

Figures 8-12. Triplectides qosqo sp. nov., male: (8) Fore and hind wings; (9) genitalia, dorsal view; (10) genitalia, lateral view; (11) phallic apparatus, lateral view; (12) genitalia, ventral view.

Holotype male: Peru, Cuzco: (19rd km W Quincemil, Río Araza tributary, $\left.874 \mathrm{~m}, 12^{\circ} 20^{\prime} 10^{\prime \prime} \mathrm{S}, 70^{\circ} 50^{\prime} 5^{\prime \prime} \mathrm{W}\right)$, Malaise trap, RR Cavichioli, JA Rafael, DM Takiya, APM Santos leg. (MUSM). Paratypes: same data as holotype, 1 male (MUSM), 4 males (DZRJ).

Distribution. Peru (province of Cuzco).

Etymology. The specific epithet, qosqo, refers to the type locality of the species, province of Cuzco. Cuzco, or Qosqo in Quechua language, is the ancient name for the capital of the great Incan Empire, meaning "navel of the world" in mystical terms.

Remarks. Triplectides qosqo sp. nov. is similar to T. nevadus Holzenthal, 1988, especially in the strongly hooked apices of the mesal lobes of inferior appendages. However, they can be easily separated by the structure of $1^{\text {st }}$ article of inferior appendages, which are much longer and narrower in the new species. Additionally, the tibial spur formula in T. nevadus is $0,2,2$ or $0,2,4$, while in $T$. qosqo it is $2,2,4$. The wing venation of the new species is virtually the same of T. nevadus.

\section{ACKNOWLEDGEMENTS}

We are grateful to Daniela M. Takiya and Allan P. Moreira dos Santos for collecting the specimens described here. The authors are also grateful to two anonymous reviewers for useful suggestions and improvements. Fundação Carlos Chagas Filho de Amparo à Pesquisa do Estado do Rio de Janeiro (FAPERJ) and Coordenação de Aperfeiçoamento de Pessoal de Nível Superior (CAPES) provided financial support. We also thank Instituto Chico Mendes de Conservação da Biodiversidade (ICMBio) for issuing collecting permits. 


\section{LITERATURE CITED}

Blahnik RJ, Holzenthal RW, Prather A (2007) The lactic acid method for clearing Trichoptera genitalia, p. 9-14. In: BuENoSoria J, Barba-Alvarez R, Armitage B (Eds) Proceedings of the $12^{\text {th }}$ International Symposium on Trichoptera. Columbus, The Caddis Press.

Dumas LL, Nessimian JL (2010) A new long-horned caddisfly in the genus Triplectides Kolenati (Trichoptera: Leptoceridae) from the Itatiaia massif, Southeastern Brazil. Neotropical Entomology 39(6): 949-951.

Hozenthal RW (1988) Sytematics of the Neotropical Triplectides (Trichoptera: Leptoceridae). Annals of the Entomological
Society of America 81(2): 186-208.

Holzenthal RW, Blahnik RJ, Prather AL, KJer KM (2007) Order Trichoptera Kirby, 1813 (Insecta), Caddisflies. In: ZHANG ZQ, Shear WA (Eds) Linnaeus Tercentenary: Progress in Invertebrate Taxonomy. Zootaxa 1668: 639-698.

Malm T, Johanson KA (2008) Description of eleven new Triplectides species (Trichoptea: Leptoceridae) from New Caledonia. Zootaxa 1816: 1-34.

Morse JC (2011) The Trichoptera world checklist. Zoosymposia 5: $372-380$.

Mosely ME (1936) A revision of the Triplectidinae, a subfamily of the Leptoceridae (Trichoptera). Transactions of the Royal Entomological Society of London 85: 91-129.

Submitted: 25 August 2014

Received in revised form: 3 December 2014

Accepted: 7 December 2014

Editorial responsibility: Gabriel L.F. Mejdalani 